\title{
Growth and accumulation of dry mass in squashes with fruiting induced by cytokinin and auxin
}

\author{
Gisele Lopes dos Santos ${ }^{1} \oplus$, Francisco Hevilásio Freire Pereira ${ }^{2}{ }^{\circ}$, Fábio Martins de Queiroga ${ }^{1} \oplus$, \\ Valéria Fernandes de Oliveira Sousa ${ }^{3}$, Diogenes Damarsio Andrade de Sousa² ${ }^{\mathbb{D}}$, \\ Joyce Emanuele de Medeiros Fernandes²

\footnotetext{
1 Universidade Federal Rural do Semi-árido, Mossoró, RN, Brasil. E-mail: gisele1612@gmail.com; fmartinsubi@gmail.com

2 Universidade Federal de Campina Grande, Campina Grande, PB, Brasil. E-mail: fhfpereira@hotmail.com; diogennes15@gmail.com; joycemanuely@hotmail.com

${ }^{3}$ Universidade Federal da Paraíba, Areia, PB, Brasil. E-mail:valeriafernandesbds@gmail.com
}

ABSTRACT: The objective of this paper was to evaluate growth and accumulation of dry mass in "Atlas" squash plants with fruiting induced by cytokinin and auxin. The work was conducted from March to June 2018. The treatments were constituted of 6 proportions of plant growth regulators, $0 / 0$ (control); 0/100; 25/75; 50/50; 75/25; 100/0\% of the concentration of 2.5 and $10.0 \mathrm{mg}$ $\mathrm{L}^{-1} \mathrm{CPPU}$ cytokinin and IBA auxin, respectively, and applied in two different ways: via ovary and through the leaves. A randomizedcomplete block design with 4 replicates was used. The results showed that all treatments affected the studied variables. The proportions $25 / 75$ and $50 / 50 \%$ applied through the leaves were the ones that best favored the growth. The use of $0 / 100 \%$ via ovary stimulates growth and accumulation of root mass, but it does not stimulate fruiting. The accumulation of fruit mass was elevated by treatments $50 / 50 \%$ via leaves and $75 / 25 \%$ via ovary.

Key words: Cucurbita moschata; indolebutyric acid; forchlorfenuron; hormone association

\section{Crescimento e acúmulo de massa seca em abóbora com frutificação induzida por citocinina e auxina}

RESUMO: O objetivo deste trabalho foi avaliar o crescimento e o acúmulo de massa seca em plantas de abóbora "Atlas" submetidas a frutificação induzida por citocinina e auxina. $O$ trabalho foi realizado no período de março a junho de 2018. Os tratamentos foram constituídos por 6 proporções de reguladores de crescimento, 0/0 (controle); 0/100; 25/75; 50/50; 75/25; $100 / 0 \%$ da concentração de 2,5 e 10,0 $\mathrm{mg} \mathrm{L}^{-1}$ da citocinina CPPU e da auxina AIB, respectivamente, e aplicados de duas formas diferentes: via ovário e foliar. $O$ delineamento experimental empregado foi o de blocos casualizados, com quatro repetições. Os resultados mostraram que todos os tratamentos influenciaram as variáveis estudadas. As proporções $25 / 75$ e $50 / 50 \%$ aplicadas via foliar foram as que melhor favoreceram o crescimento. 0 uso de $0 / 100 \%$ via ovário estimula o crescimento e o acúmulo de massa radicular, mas não promove a frutificação. $O$ acúmulo de massa de frutos foi elevado pelos tratamentos $50 / 50 \%$ via foliar e $75 / 25 \%$ via ovário.

Palavras-chave: Cucurbita moschata; ácido indolbutírico; forchlorfenuron; associação hormonal 


\section{Introduction}

In phytotechnical management of horticultural species, strategies have been sought to increase the performance. In this regard, the plant regulators - similar to phytohormones (auxins, gibberellins, cytokinins, ethylene and abscisic acid), may support these practices, once they act directly on morphology and physiology of the plants (Matos et al., 2017).

Cytokinins and auxins are involved in plant growth and its respective mass, because they stimulate cell division and elongation. They both act regularizing the organogenesis, where the auxin participates in the organ initiation and the cytokinin modulates its distribution, over the stem and the roots. They might act antagonistically controlling the aerial part ramification; in this case the auxin inhibits gene expression that regulates the cytokinin genesis and increases the gene expression involved in its degradation (Durbak et al., 2012; Neumann et al., 2017).

These hormones also affect the source-sink relationships, that is, the auxins influence the carbohydrate mobilization of the leaves and stem apex and stimulate the translocation of assimilate compounds to sink organs; and the cytokinins elevate the power of the sink organs, because of the growth stimulation and usability of sucrose (regulating the sucrolytic enzymes), besides favoring the extension of the leaf area and the photosynthetic activity of the source (Albacete et al., 2014).

The $\mathrm{N}$-(2-Chloro-4-pyridyl)-N'-phenylurea (CPPU) is a substance that has cytokinin activity focusing on the target organ because of its low translocation, and it is known to be a compound that promotes fruit growth and development (Petri et al., 2016; Inoue et al., 2018). Studies with horticultural plants have been approaching positive results caused by the use of these substances (Ding et al., 2013; Qian et al., 2018). According to El-Shraiy \& Hegazi (2010), CPPU applied via leaves in Solanum tuberosum L. favored significantly the growth parameters of the plant, when compared to the control.

The indol-3-butyric acid (IBA), belonging to the group of synthetic auxins, has presented itself as really efficient regarding plant growth, especially because it induces rooting (Mehta et al., 2018). Cato et al. (2013), working with tomato plants, observed that the IBA foliar application (5 $\mathrm{mg} \mathrm{L}^{-1}$ ) promoted a significant increase in the accumulation of dry mass in roots and fresh and dry mass in fruits.

Knowing that the use of these substances can improve the growth and development of vegetable plants, this study sought to evaluate the growth and accumulation of dry mass in squashes subjected to fruiting induced by cytokinin and auxin.

\section{Materials and Methods}

The experiment was conducted in the period from March 3rd to June 30th, in 2018, inside the Agri-food Sciences and Technology Center facilities, at the Federal University of Campina Grande, Campus of Pombal - Paraíba, Brazil. The city of Pombal is located in the West Region of Paraíba, at the coordinates $06^{\circ} 46^{\prime} \mathrm{S}, 37^{\circ} 48^{\prime} \mathrm{W}$ and altitude of $148 \mathrm{~m}$ (Beltrão et al., 2005). The climate in this region is classified, according to Alvares et al. (2013), as semiarid warm, dry, with annual average evaporation of $2000 \mathrm{~mm}$, and annual average precipitation of approximately $750 \mathrm{~mm}$ year ${ }^{-1}$.

SAKATA Atlas squash seeds were sown in polystyrene trays with 128 cells to produce seedlings. After they grew two true leaves, they were transplanted to $2-\mathrm{L}$ pots, filled with coconut fibers and commercial substrate, Topstrato HT Hortaliças $^{\circ}$, in the proportion of 3:1, respectively. Two plants were transplanted to each pot and only the most vigorous was maintained.

The treatments were constituted of six combinations (proportions) of CPPU and IBA regulators (0/0; 0/100; 25/75; $50 / 50 ; 75 / 25 ; 100 / 0 \%$, respectively) and applied in two different ways, via ovary and via leaves. The CPPU and IBA concentrations used as reference (100\%) to establish the proportions were 2.5 and $10.0 \mathrm{mg} \mathrm{L}^{-1}$, respectively. In the proportion $0 / 0 \%$ (or control), pollination occurred naturally, by bees.

The applications via ovary were executed in all pistillate flowers exogenously during the anthesis, using for that flexible ear swabs (Cotonetes ${ }^{\circ}$ ), in order to dampen the ovary wall. The first foliar application was also executed during the anthesis, with the help of manual sprayers, to wet all the leaves. Altogether, two applications were executed with an interval of 1 week. Both applications were executed within 2 hours, from 6 a.m. to 8 a.m., 20 days after the transplant. All the plants that received the hormone treatment had their pistillate flowers protected with non-woven fabric bags, 24 hours before and after the application, in order to avoid interferences derived from natural pollination.

The experimental design was the randomized complete blocks, with 6 plant hormone combinations applied in 2 different ways; with four repetitions, totaling 48 experimental units.

The irrigation was performed with drainage lysimeters, considering a leaching fraction of $10 \%$, based on a methodology previously applied by Bernardo et al. (2008). Aiming to guarantee the nourishment of the vegetables, all the irrigation water supplied was composed of a nutrient solution, diluted to $75 \%$, as proposed by Hoagland \& Arnon (1950).

Weeds were manually removed between the pots and the experimental area, in order to keep the environment free from the natural vegetation. The plants were kept in areas with reduced solar radiation (30\%). Table 1 shows the climate conditions inside these areas.

Table 1. Average of climate conditions during the experiment.

\begin{tabular}{ccc}
\hline \multicolumn{3}{c}{ Climate conditions } \\
\hline \multirow{2}{*}{ Air temperature } & Minimum & 25.09 \\
$\left({ }^{\circ} \mathrm{C}\right)$ & Average & 31.04 \\
& Maximum & 37.00 \\
Relative humidity & Minimum & 75.90 \\
$(\%)$ & Average & 80.50 \\
& Maximum & 85.10 \\
\hline
\end{tabular}


After 72 days of transplantation and complete execution of treatments, the data collection started, in order to verify the changes in the parameters.

The following items were evaluated: leaf area in $\mathrm{cm}^{2}$, obtained through the relationship of 8 leaf circles with 11.28 $\mathrm{cm}^{2}$ with the dry mass of the leaves; number of leaves, by counting all leaves in full expansion; stem diameter in $\mathrm{mm}$, determined with a digital caliper; number of branches including the main branch; main branch length, determined with the aid of a measuring tape; dry mass of the leaves, branches, roots and fruits, obtained in ovens operating at 65 으, for 72 hours. To determine the dry mass of the fruits, 500 -gram samples were collected and then put into an air circulation oven, at 65 oc for 80 hours.

The data related to the variables were submitted to the $F$ test, through variance analysis and the means were compared by the Tukey test ( $p \leq 0.05$ ), both were performed using SISVAR version 5.6 (Ferreira, 2014).

\section{Results and Discussion}

A significant interaction was noticed between the forms of application and regulators proportions for all studied variables (Table 2).

However, because the use of CPPU/IBA 0/100\% for fruit dry mass, applied via ovary, led to abortion of all flowers, it was not possible to include this treatment in the statistical analysis. Considering this effect, for fruit dry mass each regulators proportions was analyzed separately, in order to evaluate the proportion $0 / 100 \%$ applied via leaves, and in this regard only the proportions $0 / 0,25 / 75,50 / 50,75 / 25$ and $100 / 0 \%$, through the 2 different forms of application, were considered (Table 3).

For leaf area, the proportion $100 / 0 \%$ led to the most significant decreases (45.43\% and $24.40 \%)$ when applied via ovary and via leaves, respectively, in comparison to the control (0/0\%) (Figure $1 \mathrm{~A})$.

The biggest difference between the two forms of application was also observed with the $100 / 0 \%$ proportion, and foliar application led to a gain of $26.74 \%$ compared with the same proportion applied via ovary, followed by the $50 / 50$ and $25 / 75 \%$ proportions, for which the gains were
Table 3. Summary of variance analysis for fruit dry mass (FDM) of squash subjected to different regulators proportions, applied via ovary and via leaves.

\begin{tabular}{ccc}
\hline S.V. & D.F. & Mean square \\
\hline Block & FDM (via ovary) & 0.50 \\
PROP (P) & 3 & $981.67^{* *}$ \\
Residual & 4 & 0.56 \\
C.V. & 12 & 1.77 \\
Mean & & 42.40 \\
\hline & & \\
Block & FDM (via leaves) \\
PROP (P) & 3 & 0.15 \\
Residual & 5 & $1164.19^{* *}$ \\
C.V. & 15 & 0.11 \\
Mean & & 0.85 \\
\hline & & 37.97 \\
Block & FDM (interaction) & \\
APPLIC (A) & 3 & 0.39 \\
PROP (P) & 1 & $40.51^{* *}$ \\
A x P & 4 & $1732.77^{* *}$ \\
Residual & 4 & $527.79^{* *}$ \\
C.V. & 27 & 0.33 \\
Mean & & 1.39 \\
& & 41.40 \\
\hline
\end{tabular}

25.39 and $15.23 \%$, respectively. The CPPU isolated and in greater quantity, inhibited the leaf expansion, probably due to phytotoxicity.

Regarding the number of leaves, the proportions 25/75\% and $50 / 50 \%$ via leaves behaved, statistically speaking, similarly, showing an increase of $15 \%$ when compared to the control, whereas the $0 / 100 \%$ proportion applied via ovary resulted in $4.67 \%$ increase (Figure 1B). The biggest difference between the application methods was observed with the 50/50\% proportion, with an increase of $43.90 \%$ when applied via leaves. This same method (via leaves) stood out, when compared to the application via ovary, for all proportions, except for $0 / 100 \%$.

Sosnowski et al. (2016) stated that the cytokinin applied during the vegetative stage induces the increase in the number of leaves, but diminishes their expansion. However, as seen in this paper, cytokinin in equal proportion with auxin, applied on the leaves, may promote a better relationship between the expansion and the number of leaves, with a direct action on the organ, when compared with the application via ovary.

Table 2. Summary of the variance analysis for leaf area (LA), number of leaves (NL), stem diameter (SD), number of branches $(N B)$, main branch length (MBL), root length (RL), dry mass of leaves (DML), dry mass of branches (DMB) and dry mass of roots (DMR) for squash submitted to different regulators proportions applied via ovary or leaves.

\begin{tabular}{|c|c|c|c|c|c|c|c|c|c|c|}
\hline \multirow{2}{*}{ S.V. } & \multirow{2}{*}{ D.F. } & \multirow{2}{*}{$\begin{array}{c}\text { LA } \\
\left(\mathrm{cm}^{2}\right)\end{array}$} & \multirow{2}{*}{ NL } & \multirow{2}{*}{$\begin{array}{c}\text { SD } \\
(\mathrm{mm})\end{array}$} & \multirow{2}{*}{ NB } & MBL & $\mathbf{R L}$ & DML & DMB & DMR \\
\hline & & & & & & \multicolumn{2}{|c|}{$(\mathrm{cm})$} & \multicolumn{3}{|c|}{ (g) } \\
\hline Block & 3 & 301080.99 & 0.61 & 0.02 & 0.03 & 37.21 & 0.25 & 0.47 & 0.18 & 0.08 \\
\hline APPLIC (A) & 1 & $6055475.05^{* *}$ & $907.12^{* *}$ & $20.06^{* *}$ & $3.70^{* *}$ & $218.17^{* *}$ & $12.34^{* *}$ & $96.71^{* *}$ & $26.26^{* *}$ & $19.15^{* *}$ \\
\hline PROP (P) & 5 & $6370438.96^{* *}$ & $88.10^{* *}$ & $1.07^{* *}$ & $1.82^{* *}$ & $7301.10^{* *}$ & $32.11^{* *}$ & $182.22^{* *}$ & $68.52^{* *}$ & $247.68^{* *}$ \\
\hline$A \times P$ & 5 & $728185.70^{*}$ & $266.04^{* *}$ & $4.05^{* *}$ & $2.40^{* *}$ & $209.09^{* *}$ & $22.98^{* *}$ & $62.28^{* *}$ & $8.32^{* *}$ & $22.92^{* *}$ \\
\hline Residual & 33 & 261107.94 & 0.92 & 0.08 & 0.46 & 26.58 & 0.65 & 7.92 & 0.24 & 0.20 \\
\hline C.V. & & 9.52 & 1.91 & 2.70 & 18.32 & 6.37 & 2.42 & 2.36 & 5.90 & 4.80 \\
\hline Mean & & 5369.93 & 50.31 & 10.46 & 3.71 & 80.95 & 33.26 & 20.72 & 8.36 & 9.35 \\
\hline
\end{tabular}

$* *, *, "$ and ${ }^{\mathrm{ns}}$ significant at $1 \%, 5 \%$, and $10 \%$ probability levels and non-significant, respectively, by the $\mathrm{F}$ test.

S.V. - Source of variation, D.F. - Degrees of Freedom and C.V. - Coefficient of Variation. 
A.

Via ovary $\quad$ via leaves

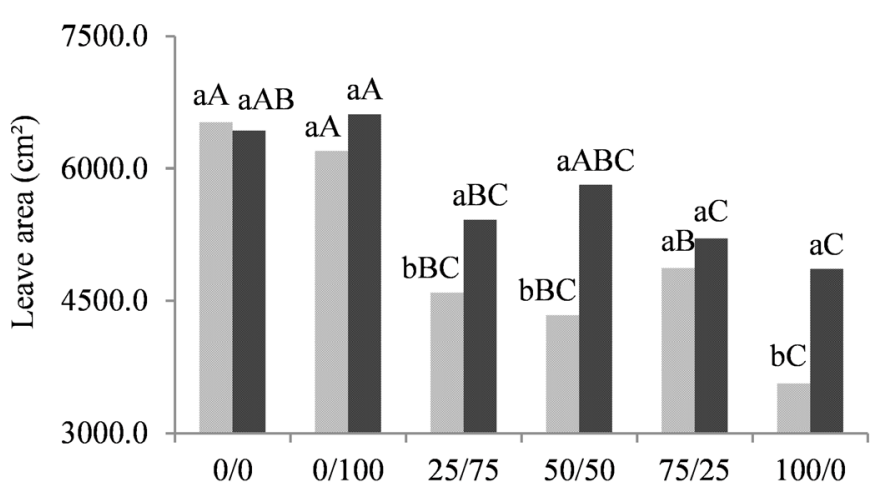

C.

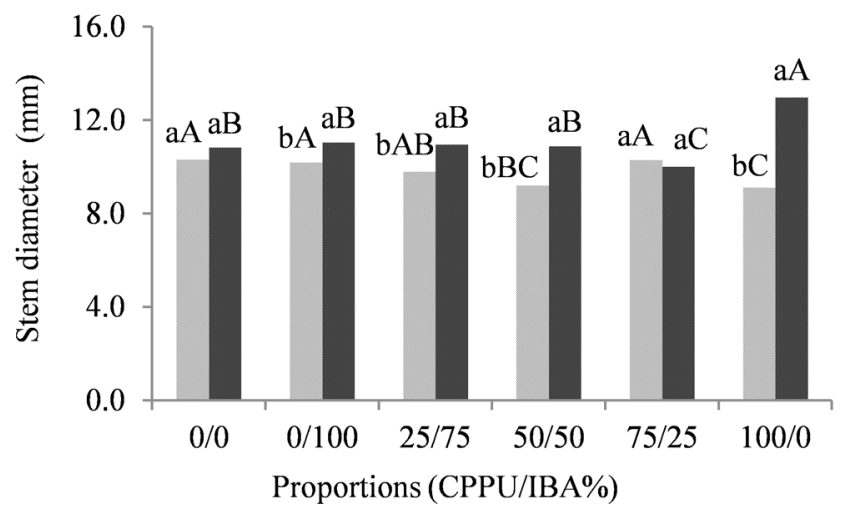

B.

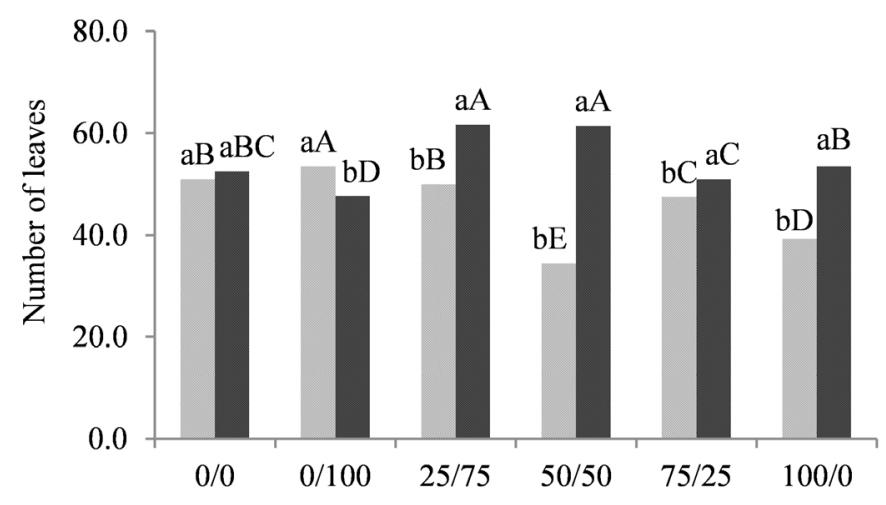

D.

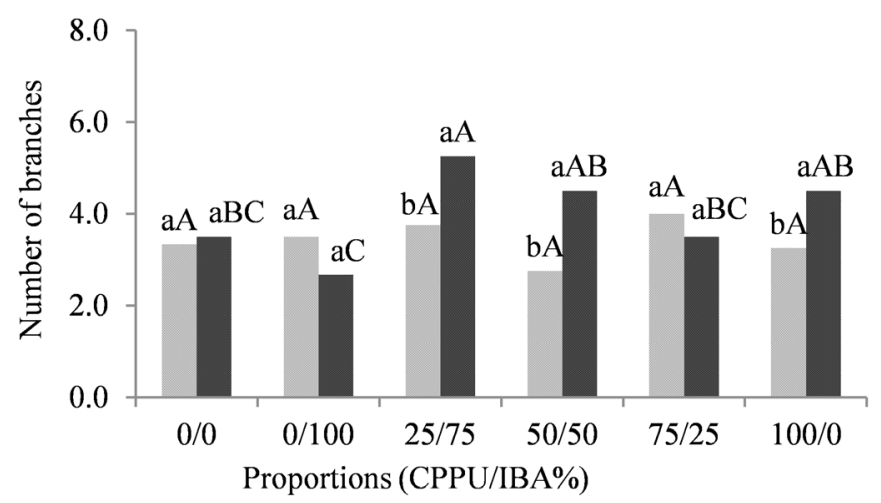

Figure 1. Leaf area (A), number of leaves (B), stem diameter (C) and number of branches (D) of squash subjected to treatment with synthetic hormones (CPPU/IBA\%), applied via ovary and via leaves. The letters above the columns indicate significant differences according to the Tukey test $(p \leq 0.05)$. The lowercase letters indicate the forms of application and the capital letters indicate the regulators proportions.

The biggest stem diameter $(12.98 \mathrm{~mm})$ was obtained with the $100 / 0 \%$ proportion via leaves, with $29.80 \%$ of difference, when compared to the same proportion applied via ovary and an increase of $16.72 \%$ when compared to the control (Figure 1C). This result for the isolated use of CPPU in the plant may be due to its action in cell expansion or because it favors the concentrations of reserves inside the stem, considering the proportion between source and sink. The exogenous application of cytokinin increases the activity of ribulose 1,5-biphospate carboxylase/oxygenase (Rubisco), optimizing the efficiency of carboxylation and the accumulation of photoassimilated compounds in the plant (Criado et al., 2009).

The number of branches increased under the proportions 25/75, 50/50 and 100/0\%, with around 5 branches per plant, when applied via leaves, that is, as the amount of CPPU increased and the amount of IBA decreased (Figure 1D), the number of branches increased (Figure 1D). Regarding the application method, foliar application proved to be superior to the application via ovary for the proportions $50 / 50 \%$ (38.89\%), 25/75\% (28.57\%) and 100/0\% (27.78\%). This happens because the cytokinin reduces the apical dominance of auxin and stimulates the growth of side branches.
Cato et al. (2013), when evaluating the synergy between auxin, gibberellin and cytokinin in tomato plants, observed that the plants that received cytokinin had reduced internodes and excessive stimulus to side buds development. Dierck et al. (2016) also state that an altered balance of cytokinin, when compared to auxin, affects the differentiation between vegetative growth and apical dominance.

The length of the main stem reduced when the hormones were administrated, when compared to the control $(0 \%)$, and the greatest reduction (64.92\%) occurred at the proportion $100 / 0 \%$ via leaves, in comparison with the control (Figure $2 \mathrm{~A}$ ). Nonetheless, when using the $0 / 100 \%$ proportion (with no CPPU), the decreases were only 20.08 and $16.54 \%$, via ovary and leaves, respectively.

The application via ovary led to better results when compared with the application via leaves, for the proportions $75 / 25 \%$ and $100 / 0 \%$ with differences of $23.94 \%$ and $23.22 \%$, respectively. Subotić et al. (2008) reported that plants treated with high CPPU concentrations had shorter blooming and the use of Thidiazuron (TDZ), another type of synthetic cytokinin, induces bad formation of the stem and the appearance of many branches. The possible hormone imbalance between the 
A.

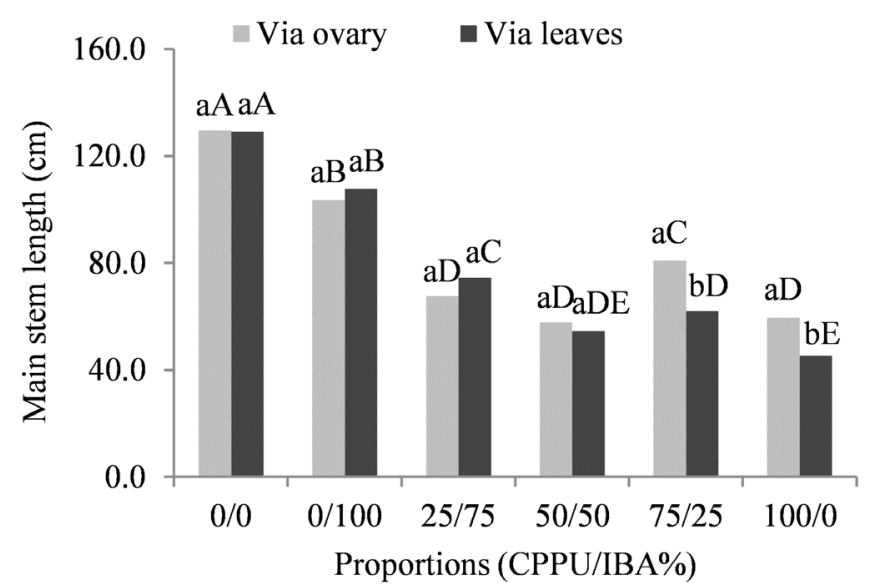

B.

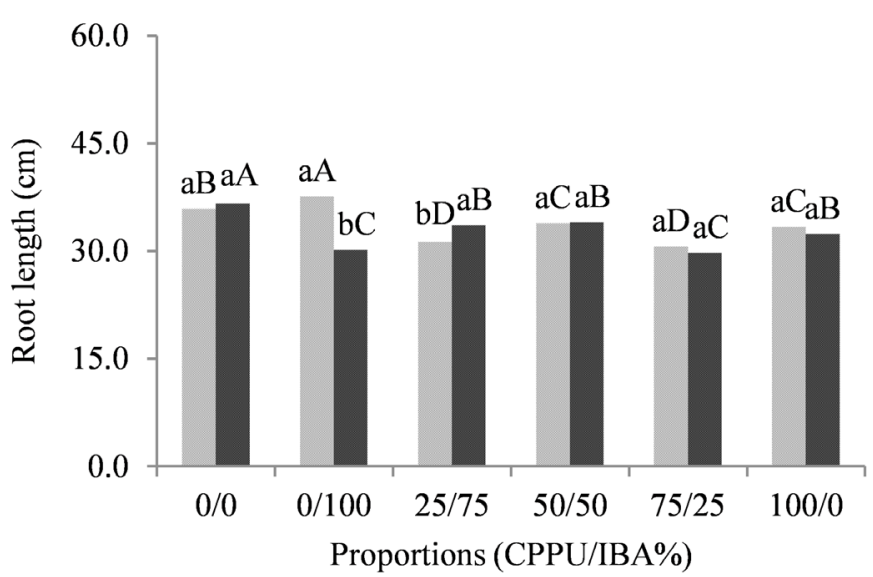

Figure 2. Main stem length $(A)$ and root length (B) of squash subjected to treatments with plant growth regulators (CPPU/IBA\%) applied via ovary and via leaves. The letters above the columns represent the differences according to the Tukey test $(p \leq 0.05)$. The lowercase letters refer to application methods and the capital letters indicate the regulators proportions.

exogenous hormones and the ones produced endogenously in the tissue treated may have inhibited plant growth. Bhogave \& Raut (2014) affirm that the use of synthetic auxin ANA via leaves favors the elongation of the plant, and this effect is not observed when IBA is used.

Root length was reduced in response to the hormone treatments in comparison with the control, except for $0 / 100 \%$ when applied via ovary, with an increase of $4.65 \%$ (Figure 2B). The opposite effect was observed when the same proportion is applied via leaves, with a reduction of $17.63 \%$ at the proportions of $0 / 0 \%$ and $19.82 \%$ when compared to the same application via ovary. The response of the plant cell to auxin depends on its concentration and location, and this can explain the induction of root growth when applied in greater proportions in the ovary. In addition, as only one organ received the hormones, its synthesis became more gradual, directing the stimulus to the aerial part of the root.

The development of the roots is mediated by the local control and, at distance, by the auxin biosynthesis. The proportion between the auxins and cytokinins determine the cell division and the differentiation in root or buds in the plant tissue, where the high concentration of auxin versus cytokinin stimulates the formation of roots (Olatunji et al., 2017; Taiz et al., 2017). As Šimášková et al. (2015) inform, an increase of cytokinin activity changes the development of the roots, restricting their growth by shortening the root meristem and, at the same time, these inhibitory effects also involve ethylene, which can explain the reduction of the root as the level of CPPU begins to rise at the other proportions.

The dry mass of leaves reduced with the hormone proportions in comparison with the control (0/0\%), except for the proportion $0 / 100 \%$ via ovary (Figure $3 \mathrm{~A}$ ). When applied via leaves, the proportion $50 / 50 \%$ was the one that most stood out, $38.28 \%$ more than the same proportion applied via ovary. As seen in this paper, the hormone proportion influenced the appearance and expansion of leaves in different ways. Therefore, this effect seems to influence the mass of leaves.
It was verified that treatments that induced the decrease in leaf area and increase in the number of leaves, as well as those which did not promote any gain for these components, compromised the mass of the leaves. On the other hand, the proportion $0 / 100 \%$ via ovary did not influence the growth of these parts and did not interfere in the accumulation of dry mass of leaves.

The dry mass of branches decreased due to the action of the regulators, with the greatest reduction (65.27\%) obtained with the $50 / 50 \%$ proportion via ovary, when compared to the control, but, statistically speaking, it is not different from the proportion $100 / 0 \%$, when applied in the same way (Figure 3B). The proportion that most reduced the mass was $0 / 100 \%$ (without CPPU), in both application methods. The application via leaves was $44.68 \%$ better than the application via ovary with the proportion $50 / 50 \%$. Because the auxin, in both application methods, did not influence the number of branches, and because it led to smaller reduction in stem length when compared to the other proportions, the loss of mass was inferior.

The proportion $0 / 100 \%$, in comparison with $0 / 0 \%$, promoted increases in dry mass of the root equal to $43.86 \%$ and $16.92 \%$ via ovary and via leaves, respectively (Figure $3 C)$. The application via ovary stood out when compared with the application via leaves, for all regulators proportions used, except for $25 / 75 \%$. This must occur because auxins are involved in the stimulation of rooting, and the increase in the IBA level is responsible for the increase in root mass. The length of the primary root meristem is moderately controlled by the auxin (El-Showk et al., 2013).

The highest value of dry mass of the fruit $(66.41 \mathrm{~g})$ was obtained with the proportion $50 / 50 \%$ was applied via leaves, followed by the $75 / 25 \%$ proportion via ovary $(61.11 \mathrm{~g})$, $70.41 \%$ and $67.67 \%$, respectively, when compared with the control (Figure 4A). The biggest divergence (36.97\%) between the two different forms of application was verified with the $50 / 50 \%$ proportion (Figure 4B). Queiroga et al. (2017) 
A.

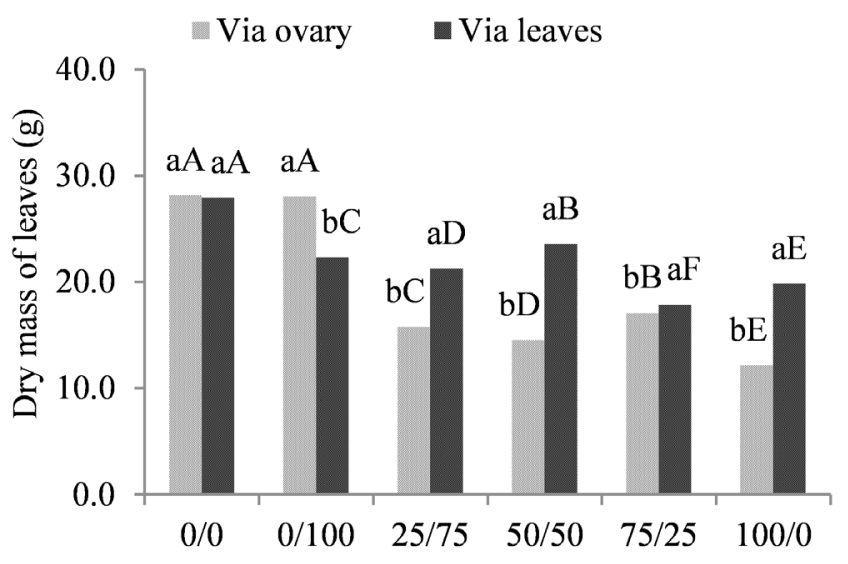

B.

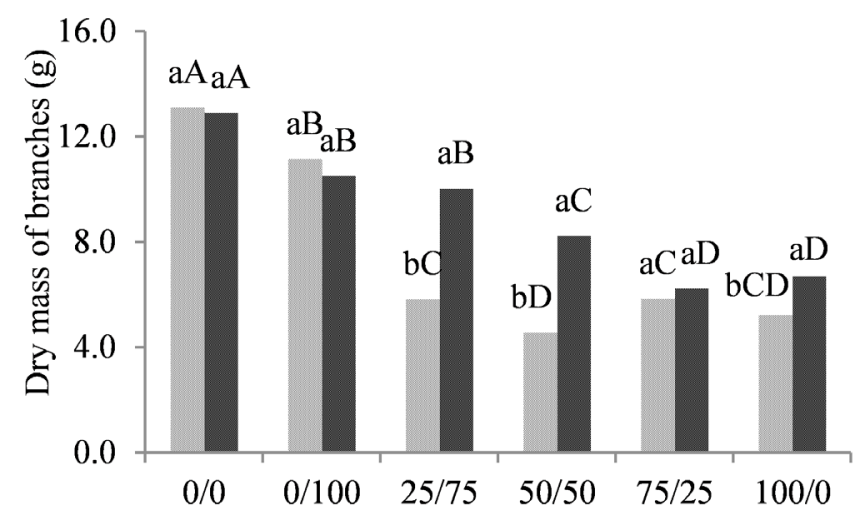

C.

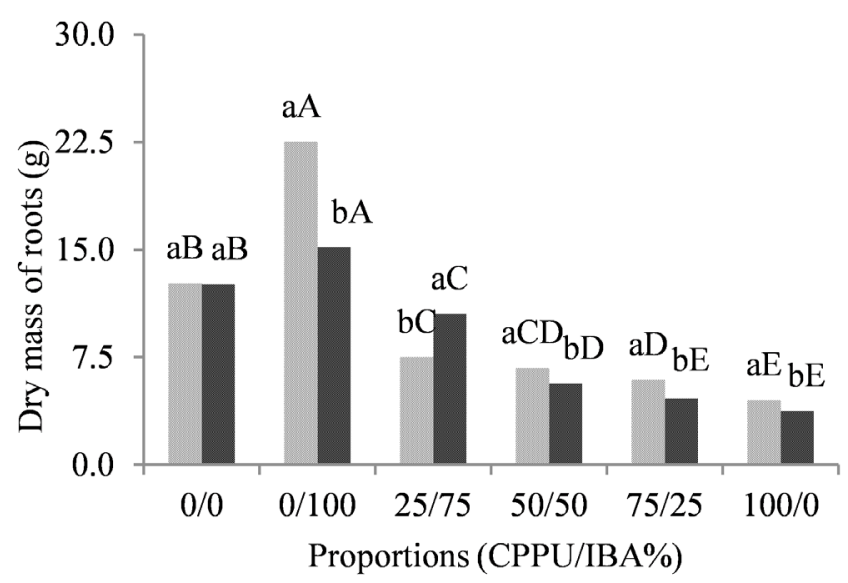

Figure 3. Dry mass of leaves (A), dry mass of branches (B) and dry mass of roots (C) of squash subjected to treatments with plant growth regulators (CPPU/IBA\%) applied via ovary and via leaves. The letters above the columns represent the differences according to the Tukey test $(p \leq 0.05)$. The lowercase letters refer to application methods and the capital letters indicate the regulators proportions.

A.

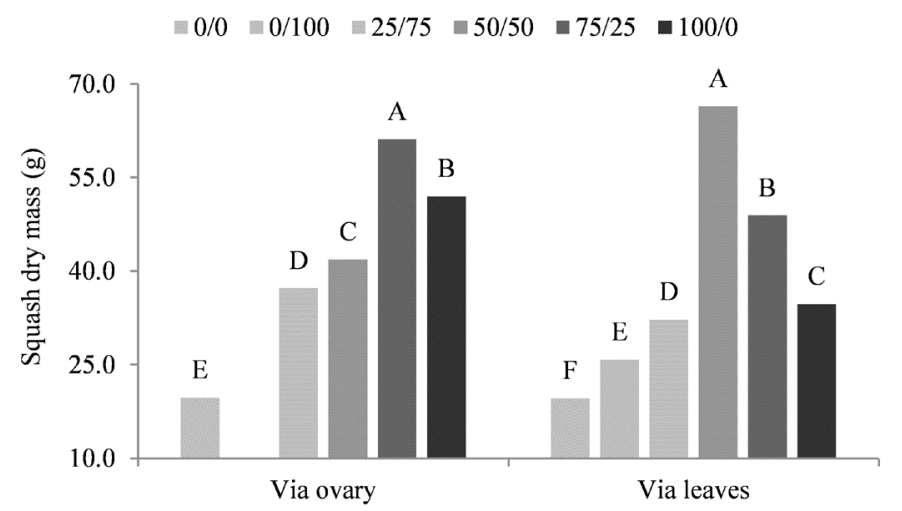

Proportions (CPPU/IBA\%)
B.

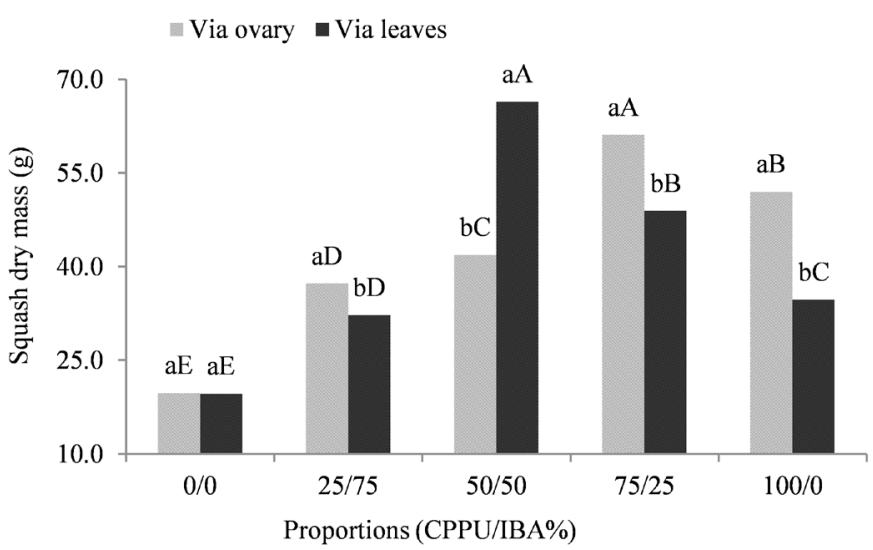

Figure 4. Squash dry mass ( $A$ and B), with fruiting induced by different hormone proportions (CPPU/IBA\%) applied via ovary and via leaves. The letters above the columns indicate significant differences according to the Tukey test $(p \leq 0.05)$. Capital letters compare different proportions and lowercase letters compare the application methods, according to each hormone proportion.

proposes that the use of compounds with auxins guarantees gains in dry mass. Cruz-Castillo et al. (2014), when studying kiwi fruits, also indicate that the pre-anthesis application of a small amount of CPPU contributed to the increase in the dry 
mass of fruits. These allegations suggest that both synthetic auxins and cytokinins may promote an increase in fruit mass, justifying why these compounds were associated, because they promoted the growth and increase in these parameters.

When analyzing the results, regarding growth characteristics, the use of CPPU (100/0\%) inhibited the leaf area in both application methods, the number of leaves and stem diameter via ovary, the length of the stem and root in both methods, as well as reduced the accumulation of dry mass of leaves, branches, roots and the total dry mass. For fruit dry mass, all proportions and application methods favored its growth.

These responses, as a consequence of abusive use of CPPU, causing saturation, may have happened because the concentration of $2.5 \mathrm{mg} \mathrm{L}^{-1}$ was high or the number of applications exceeded the necessary amount. In this case, the recommended action was to reduce one of these factors, especially when the intention is to spray the CPPU on the leaves. When IBA was applied alone $(0 / 100 \%)$ via ovary, there were no influences on these characteristics, so the treatment was similar to the control, except because it caused abortion of flowers, diminished the length and dry mass of the stem and increased the length of the root, its respective mass and total dry mass. When applied via leaves, the proportion $0 / 100 \%$ did not influence the leaf pigments, leaf area, stem diameter and the number of branches, but it did elevate the dry mass of root and fruits, besides reducing the other characteristics evaluated.

In this regard, it is possible to state that the balance between cytokinin and auxin interfere in the action and development of vegetable organs (Olatunji et al., 2017).

\section{Conclusions}

The proportions $25 / 75$ and $50 / 50 \%$ applied via leaves were the ones that most favored the growth parameters of the plants.

The greatest accumulation of fruit dry mass was promoted by the treatments with $50 / 50 \%$ via leaves and $75 / 25 \%$ via ovary.

\section{Literature Cited}

Albacete, A. A.; Martínez-Andújar, C.; Pérez-Alfocea, F. Hormonal and metabolic regulation of source-sink relations under salinity and drought: From plant survival to crop yield stability. Biotechnology Advances, v.32, n.1, p. 12-30, 2014 https://doi.org/10.1016/j. biotechadv.2013.10.005.

Alvares, C. A.; Stape, J. L.; Sentelhas, P. C.; Gonçalves, J. L. de M.; Sparovek, G. Köppen's climate classification map for Brazil. Meteorologische Zeitschrift, v.22, p.711-728, 2013. https://doi. org/10.1127/0941-2948/2013/0507.

Beltrão, B.A. Diagnóstico do município de Pombal. Projeto cadastro de fontes de abastecimento por água subterrânea. Recife: Ministério de Minas e Energia/CPRM/PRODEM, 2005. 23p.

Bernardo, S.; Soares, A. A.; Mantovani, E. C. Manual de irrigação. 8.ed. Viçosa: UFV, 2008. 625p.
Bhogave, A.F.; Raut, U.A. Studies on effect of plant growth regulators on vegetative growth and flowering of papaya. Ecology, Environment and Conservation Journal. v.21, n. 25, p.387-390, 2014. http://www.envirobiotechjournals.com/article_abstract. php?aid=5655\&iid=182\&jid=3. 22 Dez. 2018.

Cato, S.C.; Macedo, W.R.; Peres, L.E.P.; Castro, P.R.C. Synergism among auxins, gibberellins and cytokinins in tomato cv. MicroTom. Horticultura Brasileira, v.31, n.4, p. 549-553, 2013. https:// doi.org/10.1590/S0102-05362013000400007.

Criado, M. V.; Caputo, C.; Roberts, I.N.; Castro, M.A.; Barneix, A.J. Cytokinin-induced changes of nitrogen remobilization and chloroplast ultrastructure in wheat (Triticum aestivum). Journal of Plant Physiology, v. 166, n. 16, p. 1775-1785, 2009. < https:// doi.org/10.1016/j.jplph.2009.05.007.

Cruz-Castillo, J.G.; Baldicchib, A.; Frionib, T.; Marocchic, F.; Moscatellod, S.; Proiettid, S.; Battistellid, A.; Famiani, F. Preanthesis CPPU low dosage application increases 'Hayward' kiwifruit weight without affecting the other qualitative and nutritional characteristics. Food Chemistry, v.158, n.1, p.224228, 2014. https://doi.org/10.1016/j.foodchem.2014.01.131.

Dierck, R.; D Keyser, E.; De Riek, J.; Dhooghe, E.; Van Huylenbroeck, J.; Prinsen, E.; Der Straeten, D. V. Change in auxin and cytokinin levels coincides with altered expression of branching genes during axillary bud outgrowth in Chrysanthemum. Plos One, v.11, n.8, p.1-30, 2016. https://doi.org/10.1371/journal.pone.0161732

Ding, J.; Chen, B.; Xia, X.; Mao, W.; Shi, K.; Zhou, Y.; Yu, J. Cytokinin-induced parthenocarpic fruit development in tomato is partly dependent on enhanced gibberellin and auxin biosynthesis. PLoS One, v.8, n.7, p.1-17, 2013. https://doi.org/10.1371/journal.pone.0070080.

Durbak, A.; Yao, H.; Mcsteen, P. Hormone signaling in plant development. Current Opinion in Plant Biology, v. 15, n. 1, p. 9296, 2012. https://doi.org/10.1016/j.pbi.2011.12.004.

El-Showk, S.; Ruonala, R.; Helariutta, Y. Crossing paths: cytokinin signalling and crosstalk. Development, v. 140, n.1, p. 1373-1383, 2013. https://doi.org/10.1242/dev.086371.

El-Shraiy, A.M.; Hegazi, A.M. Influence of JA and CPPU on growth, yield and $\alpha$ - amylase activity in potato plant (Solanum tuberosum L.). Australian Journal of Basic and Applied Sciences, v. 4, n.2, p.160-170, 2010. https://doi.org/10.1007/s11540-007-9023-8.

Ferreira, D.F. Sisvar: A guide for its bootstrap procedures in multiple comparisons. Ciência e Agrotecnologia, v.38, n.2, p.109-112, 2014. https://doi.org/10.1590/S1413-70542014000200001.

Hoagland, D.R.; Arnon, D.L. The water culture methods for growing plants without soil. Berkeley, CA: California Agriculture Experiment Station, 1950. 32p.

Inoue, Y.; Hirano, A.; Murata, I.; Kobata, K.; Kanamoto, I. Assessment of the physical properties of inclusion complexes of forchlorfenuron and $\gamma$-cyclodextrin derivatives and their promotion of plant growth. ACS Omega, v.3, n.10, p.13160-13169, 2018. https://doi. org//10.1021/acsomega.8b01505.

Matos, J. P. De.; Correia, E. C. S. S.; Monteiro, R. N. F.; Domingues Neto, F. J.; Silva, D. P. Floração e rendimento de frutos da abobrinha italiana "Daiane" sob aplicação de regulador vegetal e fertilizante foliar. Brazilian Journal of Biosystems Engineering, v. 11, n.1, p.107-115, 2017. https://doi.org/10.18011/bioeng2017v11n1p107-115. 
Mehta, S.K.; Singh, K.K.; Harsana, A. S. Effect of IBA concentration and time of planting on rooting in pomegranate (Punica granatum) cuttings. Journal of Medicinal Plants Studies, v.6, n.1, p.250-253, 2018. http://www.plantsjournal.com/archives/2018/vol6issue1/ PartD/6-1-30-120.pdf. 10 Nov. 2018.

Neumann, E. R.; Resende, J. T. V.; Camargo, L. K. P.; Chagas, R. R.; Lima Filho, R.B. Produção de mudas de batata doce em ambiente protegido com aplicação de extrato de Ascophyllum nodosum. Horticultura Brasileira, v.35, n.4, p.490-498, 2017. https://doi. org/10.1590/s0102-053620170404.

Olatunji, D.; Geelen, D.; Verstraeten, I. Control of endogenous auxin levels in plant root development. International Journal of Molecular Sciences, v. 18, n.12, p.1-29, 2017. https://doi. org/10.3390/ijms18122587.

Petri, J. L.; Hawerroth, F. J.; Leite, G. B.; Sezerino, A. A.; Couto, M. Reguladores de crescimento para frutíferas de clima temperado. Florianópolis: Epagri, 2016. 145p.Qian, C.; Ren, N.; Wang, J.; Xu, Q.; Chen, X.; Xiaohua, Q. Effects of exogenous application of CPPU, NAA and GA4+7onparthenocarpy and fruit quality in cucumber (Cucumis sativus L.). Food Chemistry, v.243, n.15, p.410-413, 2018. https://doi.org/10.1016/j.foodchem.2017.09.150.
Queiroga, R.C.F.; Silva, G.D.; Pereira, A.M.; Almeida, R.R.P.; Silva, A.B. Yield and quality of the Tetsukabuto squash fruits induced with 2,4-D doses under dry conditions. Horticultura Brasileira, v.35, n.2, p.271-277, 2017. https://doi.org/10.1590/s0102-053620170219.

Šimášková, M.; O’brien, J.A.; Khan, M.; Noorden, G.V.; Ötvös, K.; Vieten, A. Cytokinin response factors regulate PIN-FORMED auxin transporters. Nature Communications, v.6, n.6, p.1-20, 2015. https://doi.org/10.1038/ncomms9717. Sosnowski, J.; Malinowska, E.; Jankowski, K.; Król, J.; Redzik, P. An estimation of the effects of synthetic auxin and cytokinin and the time of their application on some morphological and physiological characteristics of Medicago $\mathrm{x}$ varia T. Martyn. Saudi Journal of Biological Sciences, v.10, n.16, p.1-8. 2016. https://doi.org/10.1016/j.sjbs.2016.12.023.

Subotić, A.; Jevremović, S.; Cingel, A.; Milošević, S. Effect of urea-type citokinins on axillary shoots regeneration of Impatiens walleriana L. Biotechnology \& Biotechnological Equipment, v. 22, n. 3, p.817819, 2008. https://doi.org/10.1080/13102818.2008.10817559.

Taiz, L.; Murphy, A.; Monshausen, G. B.; Peer, W. Sinais e transdução de sinal. In: Taiz, L.; Zeiger, E.; Moller, I.M.; Murphy, A. (Orgs.). Fisiologia e desenvolvimento vegetal. 6.ed. Porto Alegre: Artmed, 2017. $888 \mathrm{p}$. 